\title{
スルースゲートを用いた弾力的な塩水遡上の 制御手法に関する基礎的研究 FLEXIBLE CONTROL OF DENSITY CURRENT MIGRATION BY USING SLUICE GATE
}

\author{
赤堀良介 $^{1} \cdot$ 吉川泰弘 $^{2} \cdot$ 安田浩保 $^{3}$ \\ Ryosuke AKAHORI, Yasuhiro YOSHIKAWA and Hiroyasu YASUDA
}

1 正会員 Ph.D. 研究員 寒地土木研究所 寒地河川チーム (= 062-8602 札幌市豊平区平岸 1 条 3 丁目 1-34)

2 正会員 工修 研究員 寒地土木研究所 寒地河川チーム（T 062-8602 札幌市豊平区平岸 1 条 3 丁目 1-34)

3 正会員 工博 新潟大学 災害復興科学センター（T 950-2181 新潟市西区五十嵐二の町 8050)

\begin{abstract}
Controlling adverse density currents has been an important issue on water quality and ecosystems of brackish water regions. This study proposes to apply sluice gate for flexible control of density current migration in open channels. Hydraulic characteristics of density flows around a sluice gate are investigated by flume experiments employing the Particle Image Velocimetry technique and numerical calculations by a Large Eddy Simulation model. The results show that the behavior of density front migration under a sluice gate is dominated by internal Froude number of both fresh water and salt water layers, and entrainment of salt water in a downstream region of a dike is influenced by evolution of instantaneous flow structures in a fresh water layer.
\end{abstract}

Key Words: density current, sluice gate, PIV, LES

\section{1. はじめに}

北海道東部に位置する網走湖を始め，河川等によって 海域と接続された閉鎖性水域においては，海域から流 入する塩水のもたらす環境への影響が問題視されてい る。このため, 接続部における塩水遡上のコントロー ルが工学的に重要な課題となっているが, 現状では河 床設置型の水理構造物に依存した抑制を行っているに 過ぎない。このような手法は塩水遡上の抑制に関して はある程度の成果を期待できる一方, 環境への影響が 大きいという問題点を有している。 また高度な制御が 必要な事態に備元起伏式やラバーゲート式のような可 動型構造物を適用した場合には, 維持コストが大きく なるという問題も生ずる。本研究では，河床に直接設 置しないために環境への負荷が小さい上，流下能力の 阻害も生じず，さらに維持コストを縮滅可能なスルー スゲートを用いた塩水遡上の制御手法を提案し，その 基礎的な特性を検討する。この手法は，河床設置型の 固定的な構造物と異なりゲート開度を自由に調節する ことが可能なため, 従来までの塩水遡上対策がフロン 卜侵入の抑制や阻止を目的としているのに対し，流入 塩水層の高さや連行現象のコントロールといった，よ り弾力的な制御を実現する可能性を秘めている.

スルースゲートと密度流の関係に関しては，二成層 場の下層からの選択的取水手法や ${ }^{1)}$, 海域に面した河 口堰を急激に開放したケース ${ }^{2)}$ などに関し先行する研
究例が存在する。これに対して本研究で取り扱う現象 は，上層の淡水が順流状態にある開水路に下層塩水が 逆流する現象に対してスルースゲートを適用するもの で，現状ではこのような条件における流体現象そのも のが十分に理解されていない.

本研究では，スルースゲートを用いた塩水遡上の制 御手法の実用化に向け, 工学的に重要となるスルース ゲートの上流区間への塩水侵入の可否，およびゲート の下流側で生じる内部跳水による淡水と塩水の混合規 模を把握することに焦点をおいた。これらの特性把握 は水理実験と数值計算の両者の組み合わせにより行う ことを試みた。水理実験については, 実験条件の設定 や制御および可視化が困難な密度流の実験をできるだ け簡便かつ省力的に実現可能な実験水路を考案すると ともに, 捕捉が困難な内部界面や流動の可視化手法を 併せて提案し, これらから得られた結果に基づき議論 を展開する。具体的には，ゲート周辺での内部界面形 状の特性を Froude 数との関連から整理し, 次に, 上層 水による下層水の連行現象について検討を行う.

このうち, 内部跳水に伴って発生する連行現象の把 握はゲートの下流区間の混合規模を把握する上で非常 に重要となる。連行現象は乱流構造の影響を受けるこ とから ${ }^{3)}$, 乱流現象を十分に解像しつつ 3 次元の非定 常問題を取り扱う上で有利な手法の一つとされる Large Eddy Simulation（LES）を用い, 乱れや流れ場の組織構 造と, 連行速度の関連から考察を行う。 


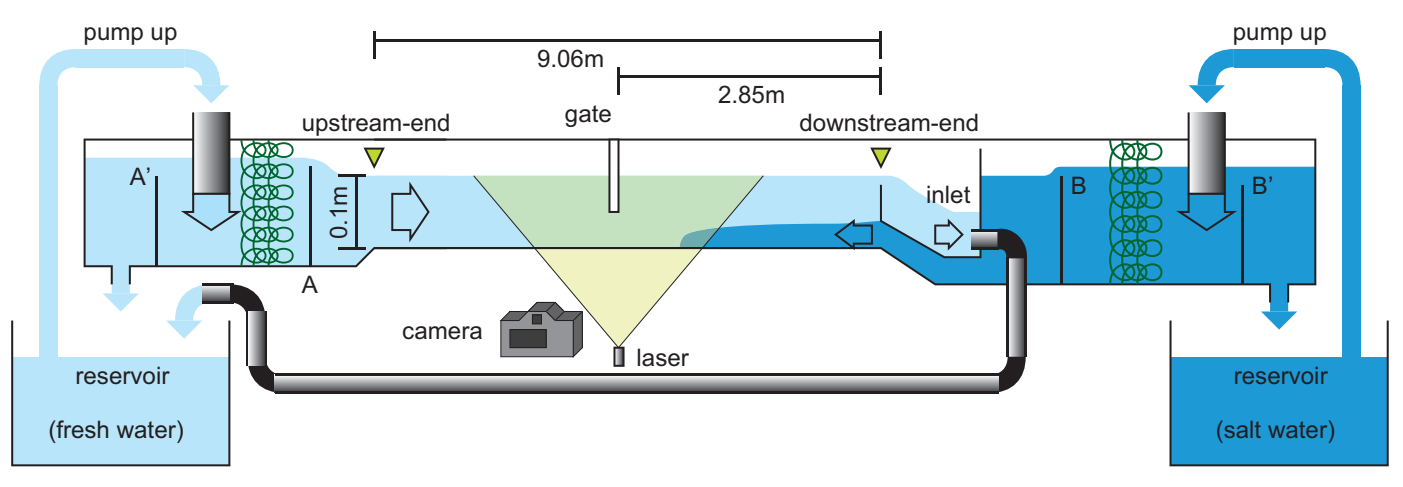

図-1 実験水路概略図

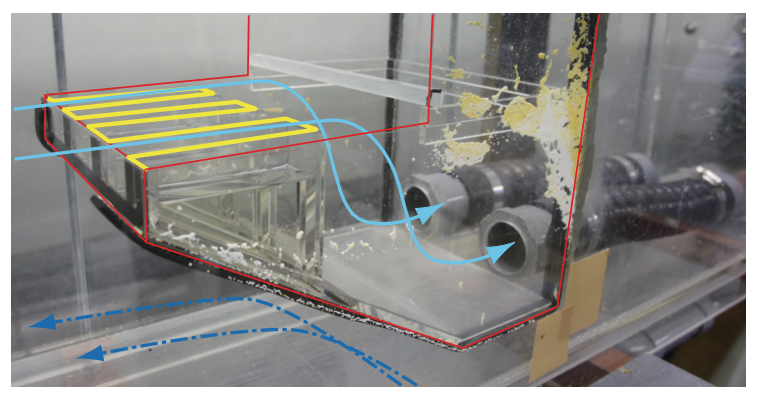

図-2 実験水路における下流側上層水取水部の様子

\section{2. 実験水路の概要}

実験水路の概要を図-1 に示す．左側が上流側，右側が 下流側である. 水路は河床および側面がアクリル板で構 成されている。実験区間の水路長は $9.2 \mathrm{~m}$, 幅は $0.2 \mathrm{~m}$, 水深は $0.1 \mathrm{~m}$ であり, 水路床勾配を 0 とした。 スルース ゲートは，水路下流端からゲート下流側の面までの距 離が $2.85 \mathrm{~m}$ となるよう設置される。淡水は上流側貯水 槽からポンプにより供給され, 堰 $\mathrm{A}$ を越流する形で侵 入し，水路内を流下した後に下流端側の上層からの取 水により再び貯水槽へと導水される. 水路下流側の取 水口を図-2 に示す。図-2 中, 実線の矢印が上層水の動 きを，鎖線の矢印が流入する塩水の動きを示し，黄色 の実線が取水部の水が落ち込む部分のエッジを, 赤の 実線が取水口周辺の構造を示す。この下流側取水部は 水路と独立しており, 取水口高さの変更を可能として いる. 上層水は取水部黄色線を越流して取水口にたど り着くが，黄色線部分を櫛形に形成することで，限ら れた水路幅内で越流部の長さを延長し, 流出端での水 位変動の影響を押さえることを試みている。一方，塩 水は下流端側の貯水槽から別のポンプにより下流側に 供給され, 堰 $\mathrm{B}$ を越流した後に図-2 の鎖線の矢印に示 すように水路下流端底面より実験水路内に導水される。

\section{3. 塩水遡上実験}

\section{(1) 実験条件}

実験条件として, 網走湖河口域での現象を対象とした 吉川ら ${ }^{4)}$ の室内実験の值を参考とした. 内部Froude 相似 則を満足させるために, 浮力加速度 $\left(g^{\prime}=\left\{\left(\rho_{1}-\rho_{2}\right) / \rho_{1}\right\} g\right.$,
ここで $\rho_{1}$ : 下層水の密度, $\rho_{2}$ : 上層水の密度, $g$ : 重力加 速度) を現地と同等になるように定め, 下層の濃度を $25.6 \mathrm{psu}$ となるよう調整している。 また内部の界面が 不安定領域にあるよう流量を定めている. 本実験では, 淡水のみ, 塩水のみ通水した場合に対して，それぞれ 流入流量が $0.0002 \mathrm{~m}^{3} / \mathrm{s}, 0.00037 \mathrm{~m}^{3} / \mathrm{s}$ となるよう設定さ れた。 またスルースゲートの高さとして, 水深に対し て開口部の高さが 50\%となるケース (Case1)，および 25\%となるケース（Case2）の2ケースを設定した。

\section{(2) 実験手法}

実験水路の水位は, 水路下流側の上層水の取水口部 分の堰の高さを事前に調整することで, ほぼ $0.1 \mathrm{~m}$ を保 つよう設定されている. 実験では, 先に順流の淡水のみ を 1 時間程度循環させ, 定常となった後に, 下流から塩 水を流入させている。 $t$ は実験開始からの経過時間を示 し, この塩水が下流端から侵入を始めた時刻を, $t=0 \mathrm{~s}$ としている. $t=0 \mathrm{~s}$ の水位は $0.100 \mathrm{~m}$ であるが, その後 若干上昇し, Case1 の下流端では $0.103 \mathrm{~m}$ 程度, Case2 の下流端においては $0.104 \mathrm{~m}$ 程度でほぼ一定となった。

実験での観測項目は，塩分濃度計（KENEK 製 NK403MSA，MKT-15-04L）による定点での塩分濃度の時 系列変化, 超音波水位計による上下流端での水位の時 系列変化, 流況の可視化および PIV 計測を目的とした デジタル一眼レフカメラ（Canon 製 EOS 5D Mark-II） による動画撮影（30fps）である。密度流現象に対する PIV 計測の適用例としては新谷らによる解析 ${ }^{5)}$ が挙げ られ, その有効性が確認されている。撮影対象は水路 下面から照射されたレーザーシート上の鉛直断面上の トレーサー粒子である。レーザーシートから水路右岸 までは $0.05 \mathrm{~m}$ の距離をとる. 可視化の際には, 上層の 淡水はフルオレセイン $\mathrm{Na}$ により着色し, 下層の塩水は 無着色とした。またトレーサー粒子として上層は白色 融解アルミナ No.1（(社）日本粉体工業技術協会製, 比 重: 3.9 - 4.0, 粒径: $0.8 \mu \mathrm{m}-5 \mu \mathrm{m})$ を, 下層にはダイヤ イオン HP20 (三菱化学製, 比重: 1.01 , 粒径: $250 \mu \mathrm{m}$ 以 上）を用いた，PIV 計測に関しては，上層，下層とも に無着色とし, トレーサー粒子にはどちらにも比重が 淡水と塩水の中間に位置するダイヤイオン HP20 を用 いた。 


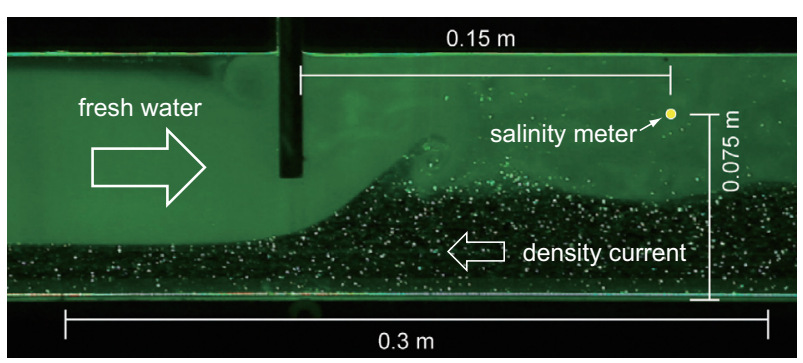

図-3 可視化のための予備実験の様子（ゲート開度 50\%）

スルースゲートの厚みを $0.01 \mathrm{~m}$, ゲート開度を $50 \%$ に 設定した場合の可視化状況を図-3に示す．ゲート下流 側で剥離した渦によって塩水が巻き上げられている様 子が確認される。測定領域は, この剥離渦の影響域を 含むよう定めるものとする。塩分濃度計位置は図-3に より示し, 左岸から $0.05 \mathrm{~m}$ の位置に設置される。また PIV による計測領域は，ゲートを基準として上流側に $0.1 \mathrm{~m}$, 下流側に $0.2 \mathrm{~m}$ とした. PIV 解析は相互相関法に より行った。解析には市販のソフトウェア（Ditect 製 Dipp-Flow）を用いている.

\section{4. 実験結果}

\section{(1) 内部界面の挙動}

図-4 および図-5 は Case1（ゲート開度 50\%）および Case2（ゲート開度 25\%）の密度境界面の分布であり, 目

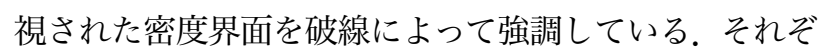
れ, 前述の塩分濃度計が一旦定常な值を示した $t=120 \mathrm{~s}$ 前後と, 再上昇を示した $t=240 \mathrm{~s}$ 前後の值で代表させ る。これは，それぞれ巻き上げられた下層の塩水が混合 しながら流下する時間帯と, 下層水の巻き上げが直接水 面に到達する時間帯に対応する。.また以降 $x$ は $x=0.0 \mathrm{~m}$ をゲート中央直下とする流下方向距離, $z$ は $z=0.0 \mathrm{~m}$ を 水路床とする鉛直方向距離とする。この図より, Case 1 （開度 50\%）では，スルースゲート下流側において密度 界面の上昇を生じさせつつも密度フロントがゲート上 流側に侵入し, 下層に塩水層を形成していることが確 認される。一方, Case2（開度 25\%）では, 密度フロン トのゲート上流への侵入が完全に抑制されていること がわかる. 図-6 は PIV 計測から得られたゲート中央直 下 $(x=0.0 \mathrm{~m})$ に打ける各ケースの流下方向流速の鉛 直方向分布を示したものであるが， $t=120 \mathrm{~s}$ からの $10 \mathrm{~s}$ 間の時間平均值, $t=240 \mathrm{~s}$ から $10 \mathrm{~s}$ 間の時間平均值に加 え, フロントの侵入直前の時点で $1 \mathrm{~s}$ 間の時間平均值も 同時に図示している. $t=120 \mathrm{~s}$ および $t=240 \mathrm{~s}$ の結果 から，ゲート直下を通過する平均流速の分布の傾向は 時間帯によって大きく変化しないことが確認できる.

この現象に関し, 内部 Froude 数による評価を行う. 内部 Froude 数は, その 2 乗の逆数が密度成層の安定度 を表す Richardson 数と等価であり, またその 3 乗の值 が連行係数と線形の関係にある ${ }^{6)}$. 本研究では, 式 (1) に定義した上層の内部 Froude 数 $\left(F_{d 2}\right)$ を用いた.
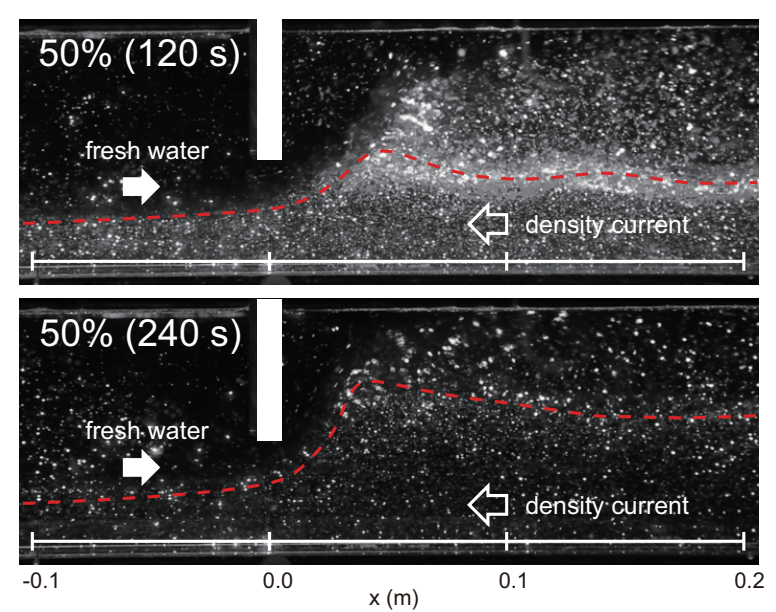

図-4 Case1（開度 50\%），120s および 240s での密度界面
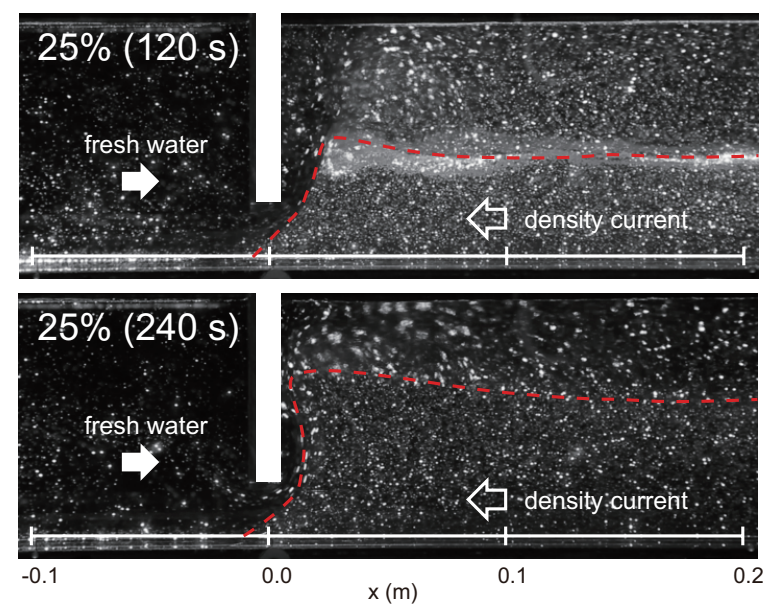

図-5 Case2（開度 25\%），120s および 240s での密度界面

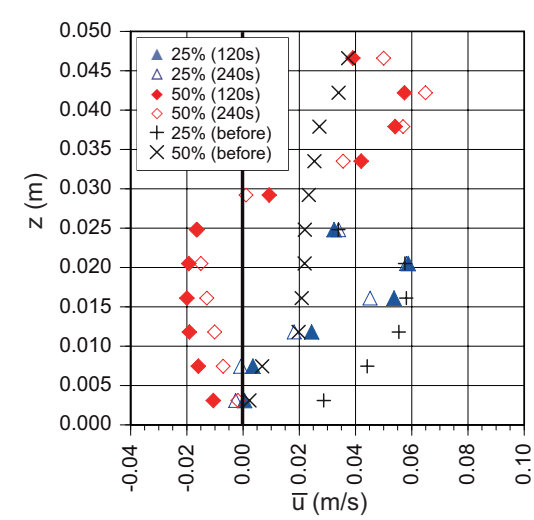

図-6 各 case のゲート直下における流下方向流速の鉛直分布

$$
F_{d 2}=\frac{\left|u_{2}\right|}{\sqrt{\left(\Delta \rho / \rho_{2}\right) g h_{2}}}
$$

ここで添字 1 は下層, 2 は上層における物理量を示 す。また $u_{2}$ は流速の最大值とし, $\rho$ は密度, $\Delta \rho$ は密度 差 $\left(\Delta \rho=\rho_{1}-\rho_{2}\right), h$ は層の層厚を示す. 図-6に示され たゲート直下の Case1（開度 50\%）120s の值から，上 層の流速 $\left(u_{2}\right)$ を最大值から $0.06 \mathrm{~m} / \mathrm{s}$ 程度とし, 図-4の 目視から $h_{1}, h_{2}$ をそれぞれ $0.033 \mathrm{~m}, 0.017 \mathrm{~m}$ とすると, 式 (1) から上層の内部 Froude 数が $F_{d 2}=0.92$ となる. 
この值が 1.0 に近いことから, Case1 のゲートの直下の 上層において上層は密度噴流領域 $\left(F_{d 2} \geq 1.0\right)$ に近く, また内部界面に関して支配断面となっており，界面水 位の上昇が上流側に伝播せずスルースゲート下流に限 定されたと考元られる。

次に図-6に示されたゲート直下の Case2（開度 25\%） $120 \mathrm{~s}$ の值を用いた場合，上層の流速（ $u_{2} ）$ を最大值から $0.06 \mathrm{~m} / \mathrm{s}$ 程度とし，図-5 の目視から $h_{1}, h_{2}$ をそれぞれ $0.008 \mathrm{~m}, 0.017 \mathrm{~m}$ とすると, 式(1)から上層の内部 Froude 数, $F_{d 2}=0.92$ を得る.これより, Case 2 もゲート直下 で $F_{d 2}$ がほぼ 1.0 となり, 支配断面に近い状態にあるこ とが確認される. Case2では開口部の高さが制限されて いることから, Case1 との比較において上層が $F_{d 2}=1.0$ となる際の $h_{1}$ の值が大きく低下し，塩水のゲート上流 への侵入層厚が小さく抑制され，密度噴流に近い上層 の流れがより底面に近い高さに存在していると考えら れる。

また, 吉川ら ${ }^{4)}$ は密度フロントの侵入を 1 次元数值 計算モデルで検討する際に，運動方程式中に密度界面 での抗力や底面での抗力の他，式 (2) に定義された形状 抵抗による抗力の項， $I_{f t 1}$ を導入し，フロント侵入速度 に関し計算精度の向上を果たしている。

$$
I_{f t 1}=-\frac{i f_{t}}{2 g h_{1}} \frac{\Delta h_{1}}{\Delta x}\left(u_{2}-u_{1}\right)\left|u_{2}-u_{1}\right|
$$

ここで $i f_{t}$ は実験的に得られるフロントの形状抵抗係 数, $\Delta h_{1} / \Delta x$ は界面の局所的な勾配, $h_{1}$ は界面の局所的 勾配を得た箇所でのフロント層厚， $u_{1}-u_{2}$ はフロント 界面における相対速度である。添字は，1がフロント を形成する塩水層， 2 がフロントの侵入していく淡水 領域を示す。本実験では，Case1（開度 50\%）の場合も Case2（開度 25\%）の場合も，ゲート近傍に到達するま での密度フロントの進行速度 $\left(u_{2}: 0.045 \mathrm{~m} / \mathrm{s}\right.$ 程度 $)$, 層 厚 $\left(h_{1}: 0.02 \mathrm{~m}\right.$ 程度 $)$ ，界面の勾配 $\left(\Delta h_{1} / \Delta x: 1 / 1\right.$ 以下 $)$ 共に，ほぼ同じ值を取ることが確認されており，式 (2) に関しケース間で異なるのは，淡水の流下速度， $u_{2}$ の 值のみとなる。図-6のフロント侵入直前の值の比較か ら, Case 1 においては $\mathrm{z}=0.02 \mathrm{~m}$ 付近で $u_{2}-u_{1}=0.04 \mathrm{~m} / \mathrm{s}$ 程度, Case 2 においては $u_{2}-u_{1}=0.08 \mathrm{~m} / \mathrm{s}$ 程度となる。 実際にはこれらの值の 2 乗が抗力に比例することから， ケース間での形状抵抗の差は大きいものと考えられる。 以上より, Case2 においてゲート近傍でのフロント周辺 の相対流速が上昇することで，フロントに働く形状抵 抗が上昇し，その侵入抑制に対し大きな影響を与えて いることが推測される。

\section{(2) 界面における連行}

スルースゲートの下流側では，界面における組織構 造等によって下層から上層に塩水が連行され ${ }^{3)}$ ，これに より水路に侵入した塩分が下流側に押し戻されている. 河道内に侵入した塩水の連行による排出は系内の塩分 量の収支上重要であり，連行現象に対するスルースゲー
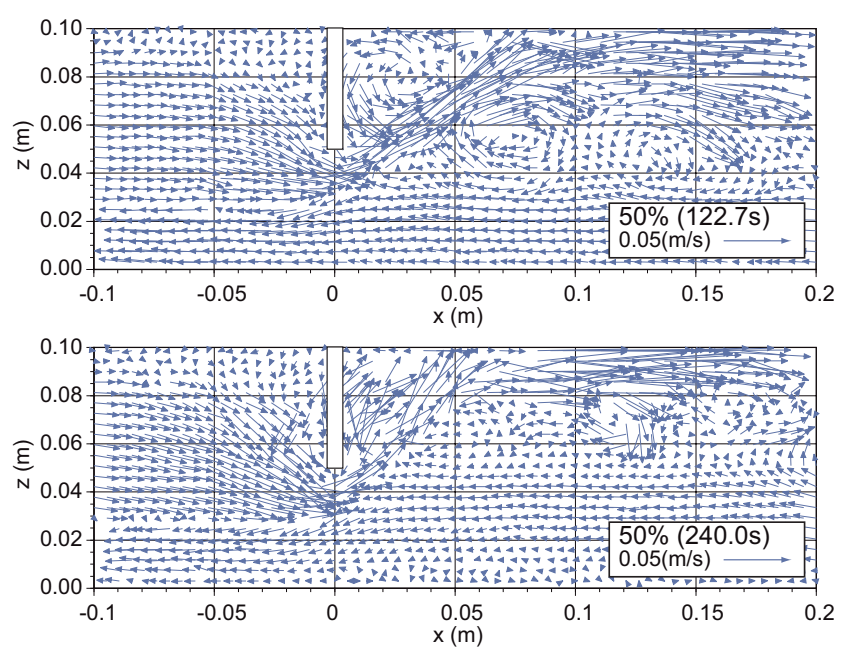

図-7 Case1（開度 50\%）における流下方向および鉛直方向流 速成分の瞬間ベクトル
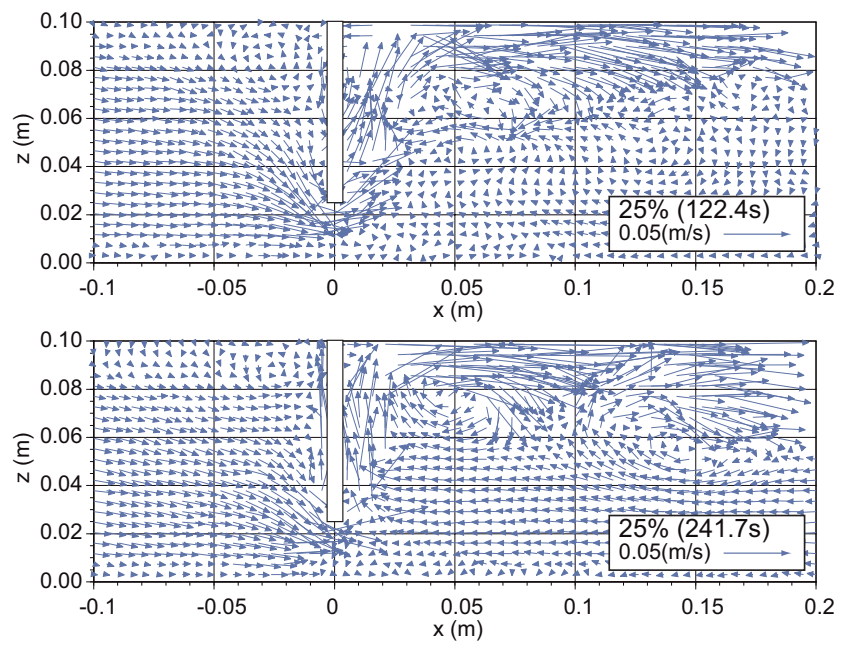

図-8 Case2（開度 25\%）における流下方向および鉛直方向流 速成分の瞬間ベクトル

トのもたらす影響の検討が必要とされる。このような 流れ場の構造による塩水遡上への影響の検討にあたり, まず各ケースの鉛直縱断面における流下方向および鉛 直方向流速成分による瞬間的なべクトルを図-7および 図-8に示す．図-7からは，Case1（ゲート開度 50\%）に おいて, 120s 前後ではゲート下から流れ出た上層水の 上流側と下流側に大きな渦が明確に生じていることが 確認出来る. 渦の構造は界面上, 流下方向に連続的に 存在している. また $240 \mathrm{~s}$ 前後では, 界面水位の上昇に 伴い, 上層水のゲートからの吹き上げの角度が急にな るほか，ゲート下流側近傍における渦の構造が $120 \mathrm{~s} の$ ものほど明瞭ではなくなっている。一方，図-8 の Case2 (ゲート開度 25\%) の場合では，ぞちらの時間帯にお いても上層水の吹き上げ角度は急であり，また下流側 近傍の渦の存在もCase1 の $120 \mathrm{~s}$ の場合ほど明瞭ではな い. 後述のスペクトル解析の結果とも合わせ, Case1 が 時間帯による乱机のスケールの変遷が大きいのに対し, Case2 はどちらの時間帯も Case1の 240s と近い傾向を 

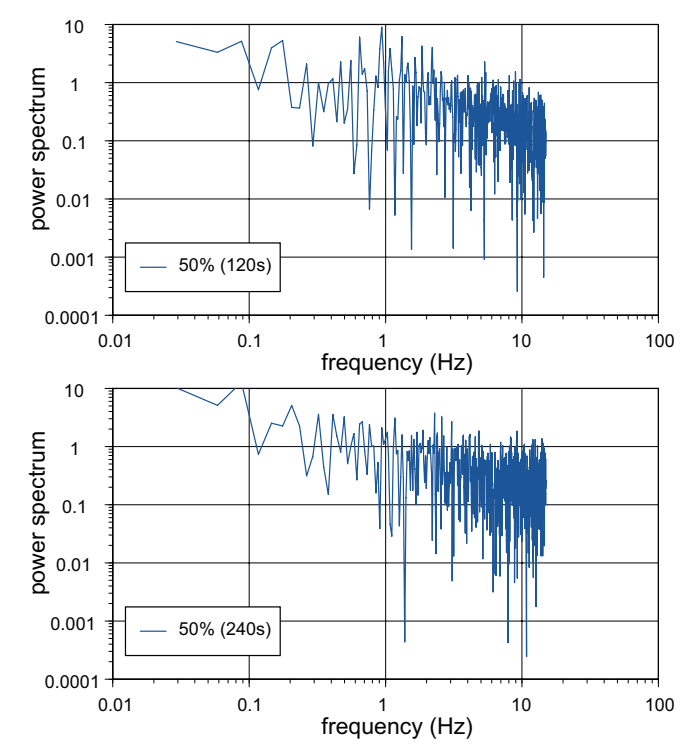

図-9 Case1（開度 50\%）ゲート近傍の渦発生地点の流下方向 流速変動成分に対するスペクトル解析

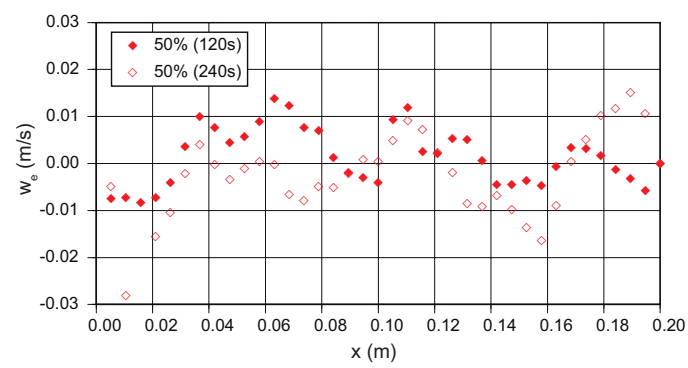

図-10 Case1（開度 $50 \%$ ）での連行速度 $w_{e}$ の流下方向分布

示したことから，以降は Case1 のみ取り上げて検討を 行う.

図-9 は Case1 の 120s および 240s からの 10s 間の各 時間帯における, ゲート最近傍の剥離渦近辺での $u^{\prime} に$ 対するスペクトル解析結果である. 結果から, 時間が進 むにつれてピークを有する周波数帯が，上り高周波成 分に移っていることが確認できる. 図-7 の結果とも合 わせ，Case1（ゲート開度 50\%）の場合，スルースゲー 卜近傍における下層水の連行に関わる乱れが，時間的， 空間的に大きなスケールを持つものから，時間が経つに つれより小さなものに変化していることが示唆される.

連行現象を定量的に評価する際には，下層から上層 に対する連行速度 $\left(w_{e}\right)$ が指標として用いられること が多い. 本論では比較的大規模な流れ場の構造による 連行を想定し, 玉井 7$) に よ り$ 定義された連行速度から 分子拡散の項を除いた式 (3)を用いてその評価を行う.

$$
w_{e}=\frac{\partial h_{2}}{\partial t}+\frac{\partial}{\partial x}\left(U_{2} h_{2}\right)
$$

添字の 2 は上層を示し， $U$ は流下方向流速の鉛直平 均值， $t$ は時間を表す。平滑化した流下方向流速の鉛 直方向分布における変曲点を界面として, 式 (3)を PIV の計測結果に対して数值的に用いる. 得られた連行速 度 $\left(w_{e}\right)$ を 10 s 間の時間平均することで，Case1（ゲー

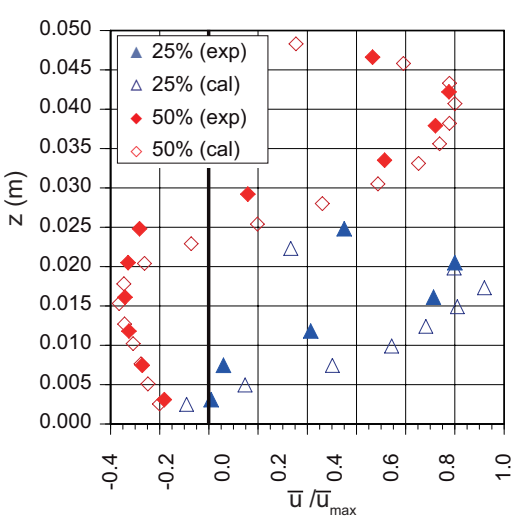

\section{図-11 ゲート下における基準化された流下方向流速の鉛直分 布に関する実験と計算の比較}

卜開度 50\%）に対して図-10の結果を得た。この結果と 図-7の比較より, Case1 において大きな連行速度を有 する領域が大規模な渦の存在する領域とほぼ重なるこ

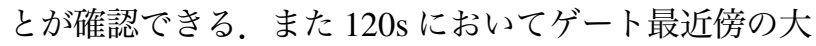

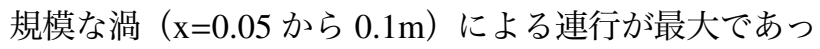
たものが，240sにおいてはその強度が低下し，下流側 での渦による連行が, 相対的に重要となっていること が確認される。

\section{5. 数値計算}

ここでは，Case1（開度 50\%）の実験結果に示された ゲート下流側乱流構造の開度や時間に応じた変遷の要 因を定性的に検討するため, 補足的に 3 次元 LES モデ ルによる数值解析を行った。 モデルは, Boussinesq 型 の浮力項を運動方程式に加えた LES モデルに, 密度の 移流拡散方程式を連立させたものである ${ }^{8)}$. 計算では水 路長のみ $8.0 \mathrm{~m}$ に変更している. 格子はゲート周辺の流 下方向刻みを細かく取った（流下 $\times$ 横断 $\times$ 鉛直: $300 \times$ $40 \times 40 ＼mathrm{~ ． 境 界 条 件 は ， 上 流 端 か ら 淡 水 を ~} 0.0002 \mathrm{~m}^{3} / \mathrm{s}$ 流入させ, 下流側では上層側を自由流出, 下層側から は $0.0002 \mathrm{~m}^{3} / \mathrm{s}$ の塩水を流入させている（ゲート周辺の 実験時の塩水流量が設定值より大幅に小さくなること から，適宜小さめの值を与えた）。

図-11 は，フロントのゲート到達から 60s 程度後の流 下方向流速に関して, ゲート下の鉛直方向分布を実験 と計算で比較したものである。ここで, 流速は実験お よび計算の最大值（それぞれ $0.06 \mathrm{~m} / \mathrm{s}, 0.08 \mathrm{~m} / \mathrm{s}$ ) によっ て基準化されている。結果から, Case1（開度 50\%）と Case2（開度 25\%）での相対的な傾向などが再現されて いることが確認される. 定量的な再現性は現在のとこ ろ十分ではないが，これは流下方向の格子間隔の設定 が一定でない点や, 境界での流入, 流出条件が, 実験 での複雑な状況を十分に反映出来ていない点などが原 因として考えられる。

瞬間的な流れ場の構造を把握するにあたり, 回転す る渦の中心軸を圧力極小の等值面で可視化する $\lambda_{2}$ 法 9）を用いた。図-12 上図は計算結果における Case1（開 
度 50\%）のフロントのゲート到達 60s 後における $\lambda_{2}$ の等值面（ $\lambda_{2}=-4.0$, 白色の等值面），密度等值面 $\left(\rho=1012.5 \mathrm{~kg} / \mathrm{m}^{3}\right.$, 緑色の等値面 $)$, 鉛直断面での密度 コンターを示し, 図-12 下図はそこから 70s 後の状況を 示したものである。上図においては，特にゲート最近 傍の剥離渦の軸が横断方向に一様で 2 次元的な構造を 有しているのに対し (図の赤枠内), 下図では横断方向 の軸の形は奥行き方向の一様性を失い（黄枠内），2次 元的というょりは 3 次元的な様相を呈している.

図-13 は，計算結果 (Case1: 50\%) 中央縦断面におけ る連行速度の流下方向分布の $10 \mathrm{~s}$ 間の平均值を, ゲー 卜到達後 $60 \mathrm{~s}$ と, そこから $70 \mathrm{~s}$ 後について示したもの である。連行速度計算時の密度境界面の定義を, 密度 $1012.5\left(\mathrm{~kg} / \mathrm{m}^{3}\right)$ で定義している. 図-10 との比較では，ど ちらも $\mathrm{x}=0.05 \mathrm{~m}$ から $0.1 \mathrm{~m}$ にかけての連行速度が時間の 経過とともに低下し, 相対的に下流側の連行速度が重要 となる傾向が確認出来る. 図-12 との比較からは, ゲー 卜到後 $60 \mathrm{~s}$ における高い連行速度を有する $\mathrm{x}=0.05 \mathrm{~m}$ か ら $0.1 \mathrm{~m}$ の領域が，図-12 内の横断方向に一様で 2 次元 的な渦 (赤枠) とほぼ位置的に一致すること，またゲー 卜到達後 130s では, 同じ領域での連行速度は低下して おり, これは横断方向の一様性を失った渦構造（黄枠） と対応することが確認出来る。

これらより，Case1（開度 50\%）の 120s での下層水 の連行が，横断方向に一様な軸を有する大規模な渦の 構造に依存するのに対し, Case1の 240s ではその渦が 横断方向の一椂性を失い, 空間的，時間的スケールが 低下することで連行速度も低下したことが推測される。

\section{6. まとめ}

本研究では, 河口域での塩水遡上の制御を目的とし たスルースゲートの利用を提案し, 室内実験によりそ の特性の検討を行った. 実験結果により, 密度フロント の進行が内部 Froude 数の影響を強く受けており, ゲー トの開口部の調整によって, 下層水の層厚を押さえ，か つ上層の淡水層の内部 Froude 数が 1.0 を上回る状況を 設定した場合，フロントの上流側への進行がほぼ抑制 出来ることが確認された。すなわち, 塩水の遡上量に応 じたゲート開度を設定することで, 弾力的な塩水遡上 の制御が実現される可能性が示唆されたと考えられる. またゲート下流側での界面に生じた渦による連行は ゲートを通過した上層の流れの構造に依存し, 渦の空 間的，時間的スケールが大きい場合に，連行速度が大 きくなることが確認された。

\section{参考文献}

1) Jirka, G. H.:Supercritical withdrawal from two-layered fluid systems -Part 1: Two-dimensional skimmer wall, J. Hyd. Res., Vol.17, No.1, pp.43-51, 1979.

2) 玉井信行, 廣沢佑哺, 福嶋祐介 : 水門から侵入する非定 常二層流について, 第 30 回年次学術講演会講演集, II, pp.442-443, 1975.
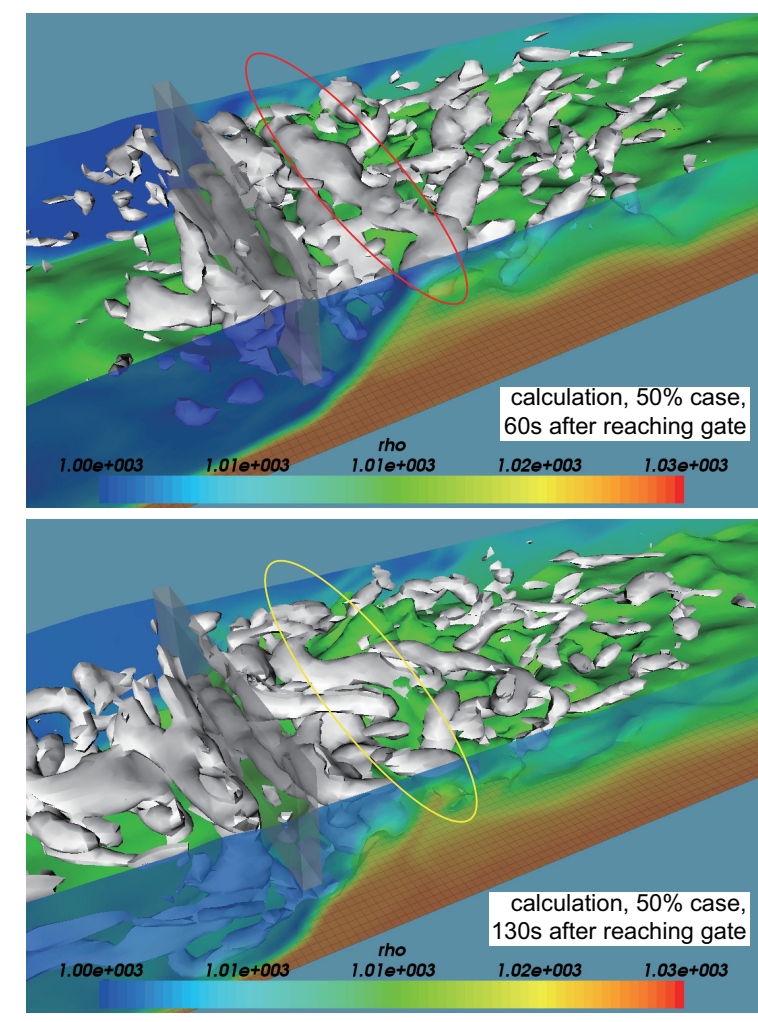

図-12 $\lambda_{2}=-4.0$ の等值面 (白) で示された瞬間構造の回転軸, $\rho=1012.5 \mathrm{~kg} / \mathbf{m}^{3}$ の等値面 (緑), および密度コンター

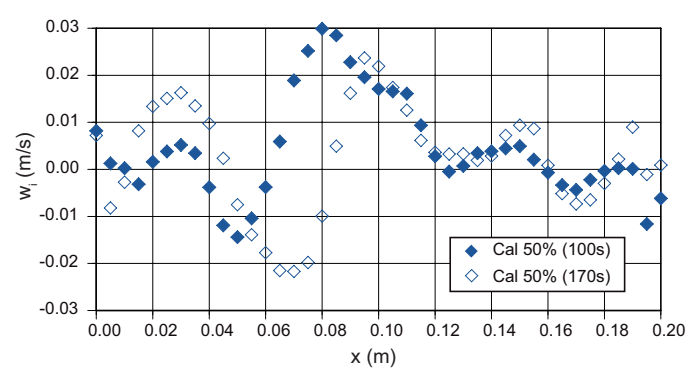

図-13 計算結果: Case1（開度 $50 \%$ ）の連行速度 $w_{e}$ の流下 方向分布

3) 浦 勝, 廣畑浩司: 二成層場の吹送流の乱流構造と連行現 象，第 31 回海岸工学講演会論文集，pp.650-654, 1984.

4) 吉川泰弘, 安田浩保, 渡邊康玄: 透過性構造物による塩水遡 上抑制効果についての研究, 寒地土木研究所月報, No.657, pp.2-14, 2008.

5) 新谷哲也, 梅山元彦: PIV 法と画像処理を用いた成層水中 の流動·混合解析, 水工学論文集, 第 48 巻, pp.1381-1386, 2004.

6) 有田正光 編著: 水圈の環境, 東京電気大学出版局, 1998 .

7) 玉井信行 : 連行概念の統一化と連行係数の評価法, 土木学 会論文集, No.381/II-7, pp.1-11, 1987.

8) 赤堀良介：密度フロント侵入抑止を目的とした堰周辺で の 3 次元的な流れ場に対する検討, 水工学論文集, 第 54 巻, pp.1429-1434, 2010.

9) Jeong, J. and Hussain, F.: On the Identification of a Vortex, $J$. Fluid Mech., Vol. 285, pp.69-94, 1995.

(2010.9.30 受付) 